\title{
Social Capital and Student Achievement: Exploring the Influence of Social Relationships on School Success in Norway and Romania
}

\author{
Lihong Huang1*, Diana Dămean², David Cairns ${ }^{3}$ \\ ${ }^{1}$ NOVA-Norwegian Social Research, Oslo and Akershus University College of Applied Sciences, Oslo, Norway \\ ${ }^{2}$ Faculty of Sociology and Social Work, Babes-Bolyai University, Cluj-Napoca, Romania \\ ${ }^{3}$ Centre for Research and Studies in Sociology, University Institute of Lisbon, Avenida das Forças Armadas, \\ ISCTE, Lisbon, Portugal \\ Email: ㄴihong.Huang@nova.hioa.no, damean_diana@yahoo.com, David.Cairns@iscte.pt
}

Received 4 May 2015; accepted 1 September 2015; published 4 September 2015

Copyright (C) 2015 by authors and Scientific Research Publishing Inc.

This work is licensed under the Creative Commons Attribution International License (CC BY).

http://creativecommons.org/licenses/by/4.0/

\section{(c) (i) Open Access}

\begin{abstract}
This paper investigates student social relationships in secondary schools and its relationship with student achievement in Norway and Romania. Using data from national youth surveys ("Young in Norway 2010" for Norway and "School Success Profile Survey 2010" for Romania), we explore the concept and measurement of social capital in the school context by applying factor analysis. The paper also tests an analytical model that links student home background, student social capital and student academic achievement, using a structural equation modelling technique (LISREL). Control variables in the analysis are student gender and ethnicity. Testing the analytical model with the two datasets respectively, the results show that student social capital, generated from student social relations with parents, teachers and peers, has a significant influence on student achievement in both countries. Analysis also confirms differences between the two countries in respect to the effect of home background variables and social capital on achievement.
\end{abstract}

\section{Keywords}

Norway, Romania, Social Capital, Student Achievement, Schools

\footnotetext{
${ }^{*}$ Corresponding author.

How to cite this paper: Huang, L. H., Dămean, D., \& Cairns, D. (2015). Social Capital and Student Achievement: Exploring the Influence of Social Relationships on School Success in Norway and Romania. Creative Education, 6, 1638-1649. http://dx.doi.org/10.4236/ce.2015.615166
} 


\section{Introduction}

On the surface, Norway and Romania appear as two contrasting European countries: the former is a relatively young country, independent since 1905, with a political system representative of advanced Western democracy, while the later has a long history, characterized in the recent past by several decades of communist rule. In economic terms, Norway is a high income country with a PPP gross national income (GNI) per capita of 57,000 US\$ and Romania, with a PPP GNI per capita of 14,000 US\$, belongs to the category of upper middle income countries according to the development indicators of the World Bank (2012). But in respect to secondary education systems, the difference between the two countries is less marked. According to UNESCO (2012), compulsory education in both countries lasts for a period of 10 years, from the age of 6 until 16, and gross enrolment rate is high: 99\% in Norway and 96\% in Romania; transition rate from primary to secondary is $100 \%$ in Norway and $98.5 \%$ in Romania; and both countries have achieved gender parity in compulsory education, with women now the majority students at tertiary education level in both these countries (see Figure 1).

Figure 1 also shows a similar pattern of educational development for both countries in the past two decades, with enrolments in primary and secondary education remain relatively stable from 1991 to 2009 and tertiary education experiencing major increases in participation, with Romania, as a country in transition during this time, witnessing a clear rise in primary education enrolments and a huge increase at tertiary education level. And it appears to be the case that both systems have achieved and maintained gender equality in education during this time. However, the school systems are structured differently in these two countries, with post-compulsory school for 3 years at upper secondary level in Norway and 2 years in Romania. Moreover, the two countries differ in terms of the quality of education; for example, $6 \%$ of Norwegian students were of the lowest proficiency on PISA mathematics in 2009 while for Romania the equivalent figure is 20\% (UNESCO, 2012).

These initial reflections lead towards a consideration of policies aimed at increasing equality in education systems. Such policies have deep roots in both countries, with constitutional legislation supporting participation among all citizens regardless of social and cultural background, gender, place of residence or special needs. However, as in many other societies (Cabrera \& La Nasa, 2001; Choy et al., 2000; Erikson \& Jonsson, 1998; Hu, 2003; Husén, 1989; OECD, 2005; Huang \& Sabastian, 2014), differentials are still to be found in relation to education outcomes related to structural factors and socio-economic backgrounds in Norway and Romania. In the former, as in many other countries, gender differentials in school achievement have shifted in favour of females (Lie et al., 2001; OECD, 2005; McDaniel, 2010); however, this does not change the reality of a gendersegmented labour market in Norway, with a persistent gender gap disfavouring women in regard to leadership positions and salary levels (Huang, 2009a). Romania, having achieved equal gender enrolments under its previous socialist regime, has been facing a higher rate of rural and Roma females dropping out from non-compulsory levels of schools (Silova \& Magno, 2004). An achievement gap is also consistently found in Norway between the majority youth population and 1) young people from families in which both parents are no

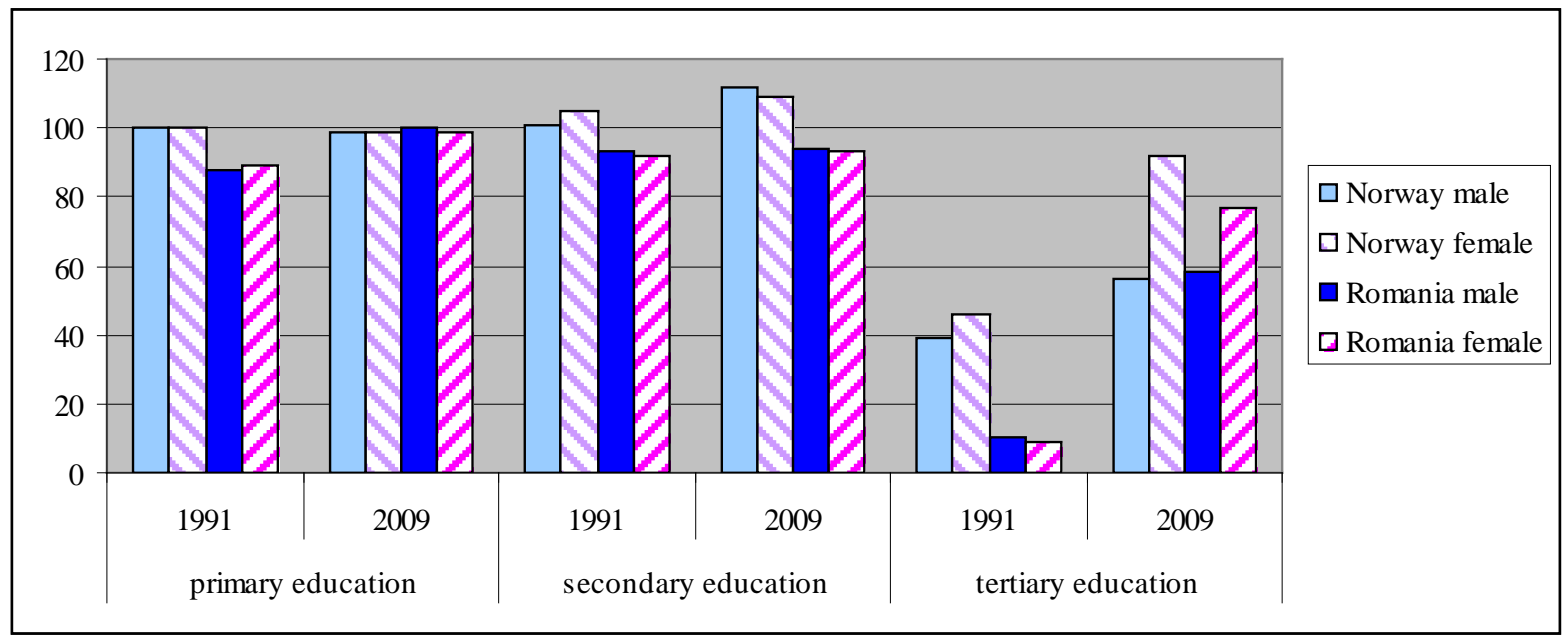

Figure 1. Gross enrolment ratio in education in Norway and Romanian by gender (\% of relevant age group). NOTE: data source: World Bank (2012) Table A1 Page 383. 
longer living together (Lauglo, 2008); 2) young people from minority backgrounds (Lauglo, 1996; Krange \& Bakken, 1998); 3) young people with special educational needs in school (Markussen et al., 2007; Huang, 2008). In Romania, school achievement gaps persist 1) across regions and between rural/urban areas due to structural inequality (Miclea, 2005); 2) between young people of different ethnic backgrounds, related to social deprivation and the exclusion of Roma people (Jigău et al., 2002; Silova \& Magno, 2004; Dămean, 2010); and 3) between young people according to levels of social and economic resources at home and at school (Agabrian, 2007; Hatos, 2008; Tufiş, 2008).

This last reflection leads us to the main research question of this article, which explores the relationship between social capital in secondary schools and student achievement in Norway and Romania. The decision to concentrate upon education systems is based on the fact that prior international research has already explored the significance of social and economic resources at home. For example, the effect of home socio-economic background has been found to have a persistent but generally weak effect upon student achievement (Buru-Bellat, 2004). It has also been discovered that in addition to the influence of human and economic capital at home, home structure and residential stability can influence parental expectations, parent-child communications, type of school attended, and parent-school cooperation; factors that are, in turn, strongly associated with student achievement (Güzel \& Berberoglu, 2005; Huang, 2009b; Meier, 1999; Sandefur \& Wells, 1999; Sandefur et al., 2006; Cairns, 2013, 2014). But we also know that as human capital is transferred, at least partly, through interaction between parents and their children, families with high levels of human capital but low levels of interaction do not necessarily guarantee a child's success in school.

Human and economic capital in the home seems to be more easily translated into success at school when a good child-parent relationship is also present (Teachman et al., 1996). Moreover, children connect and interact not only with their parents but also with others outside the home, especially peers and teachers at school. These outside relationships are also found to influence a child's development (Harding, 2003; McDonough, 1997) and eventually his/her educational achievement (Olsen, 2003; Huang, 2009b, 2010), making it difficult to draw conclusions about the relationship between social capital and home environment. It should also be acknowledged that empirical research on these issues is limited and often conducted within a specific territory of a school or a community or a country, most often applying qualitative methods. We therefore lack a holistic view on children's social relations as forged at home, school, the community and the wider society or the actual impact of these social relations on the wellbeing of the child. And international studies such as PISA student questionnaires have made it possible for quantitative analysis and international comparison to be made but only on the effect of student-teacher relations (Olsen, 2003).

In this study, we aim to contribute to our understanding of the role of social capital in educational contexts through the use of available data from national youth surveys conducted in schools in Norway ("Young in Norway” 2010) and in Romania ("The School Success Profile Survey” 2010). This evidence-based discussion compares student social capital and its association with academic achievement at schools in both these countries, with the intention of establishing the strength or weakness of the relationship between levels of social capital in education systems and educational attainment. In what follows, we introduce our social capital analytical framework through discussion of prior studies and theoretical perspectives, before moving onto a description of data sources and methods applied in the analysis. This leads to a discussion of results and conclusions relating to the significance of our findings for our understanding of academic achievement.

\section{Theoretical Context: Social Capital in a School Context}

The concept of social capital is well established as a theoretical tool across the social sciences, including educational contexts. While there is no consensus as to a precise definition, most major theorists are in agreement that social networks, including family ties and peer relationships, are of fundamental importance to the creation and maintenance of this resource (Field, 2003: p. 1), contingent upon features of social organization such as 'trust, norms, and networks' (Putnam, 1993: p. 169), with investment in social relations related to expected returns in the marketplace (Lin, 2001: p. 19). One's stock of social capital can hence be estimated from the strength and breadth of connections between people who live, work and study together, or who share common values or cultural heritage. These links help can people in tasks ranging from finding a job to avoiding anomie, as well as inhibit the development of wider social horizons and excluding outsiders.

Although the concept has its roots in the classical theory of de Tocqueville and Durkheim on social organization, as well as engaging with foundations established by Marx and Weber (Portes, 1998), awareness of social 
capital within the social sciences is high due to the influential work of Bourdieu (1997), Putnam (2000) and Coleman (1988), who with their numerous followers have made the application of the concept commonplace. This includes work conducted in educational contexts, influenced by Coleman's pioneering work in this field. One aspect of this work of relevance to the present study is the idea that the level of "connectedness" between a child and his or her family, friends, community and school is as important as family socio-economic background. This "connectedness" is a product of social relationships and social involvement, which generates social capital. Coleman further suggests that the concept of social capital serves as a mechanism for transmitting the effects of family human capital from parents to children. Subsequent studies have emphasized the importance of both general (i.e. structural) and subjective (i.e. relationships between actors) aspects of social capital (Teachman et al., 1996) and of interpersonal relationships and the resources that individuals use to advance their purposes (Schoen et al., 1997), demarcating two distinct categories of social capital: forms and benefits (Sandefur \& Laumann, 1998).

Astone et al. (1999) identify three dimensions of social capital: forms of social capital (i.e. relationships); quality of social capital (i.e. interactions within the relationships); and the resources available via a form of social capital (i.e. the effects), which have previously been applied to school context (Huang, 2009b) and will form the basis of the present analysis. The justification for this choice relates to the fact that at the outset, students from the same social milieu and educational system largely in theory possess the same forms of social relations; a child's relationship with his or her parents is forged at birth while relationships with teachers and peers are formed at school. However, even when home and school socio-economic conditions are controlled for, some children will typically have more activated relationships, or more activities taking place in their relationships, than others. These relational interactions can be characterized as friendly or conflictual. Therefore, the quality of relationships and interactions vary among children, and relationships with different qualities will eventually, to various degrees, act as positive or negative influences on wellbeing and future development. Based on such assumptions, Huang (2009b) has proposed an analytical framework (see Figure 2) for testing the effect of student social capital on educational achievement.

This framework rests on the assumption that the social capital available to or potentially generated for a student is formed in three contexts: home, community (or neighbourhood), and school. The quality of relationships within the family can lead to parental involvement in and assistance to their child's schooling (Coleman, 1988; Sandefur et al., 2006; Teachman et al., 1996). Relationships with teachers can provide access to information and opportunities that enhance the educational performance of children (Hill \& Rowe, 1996, 1998; Rowe, 1997; Meier, 1999) and the same can be said about relationships with friends and/or peers (Stanton-Salazar \& Dornbusch, 1995). It is hypothesized in the framework that background variables can have both direct and indirect

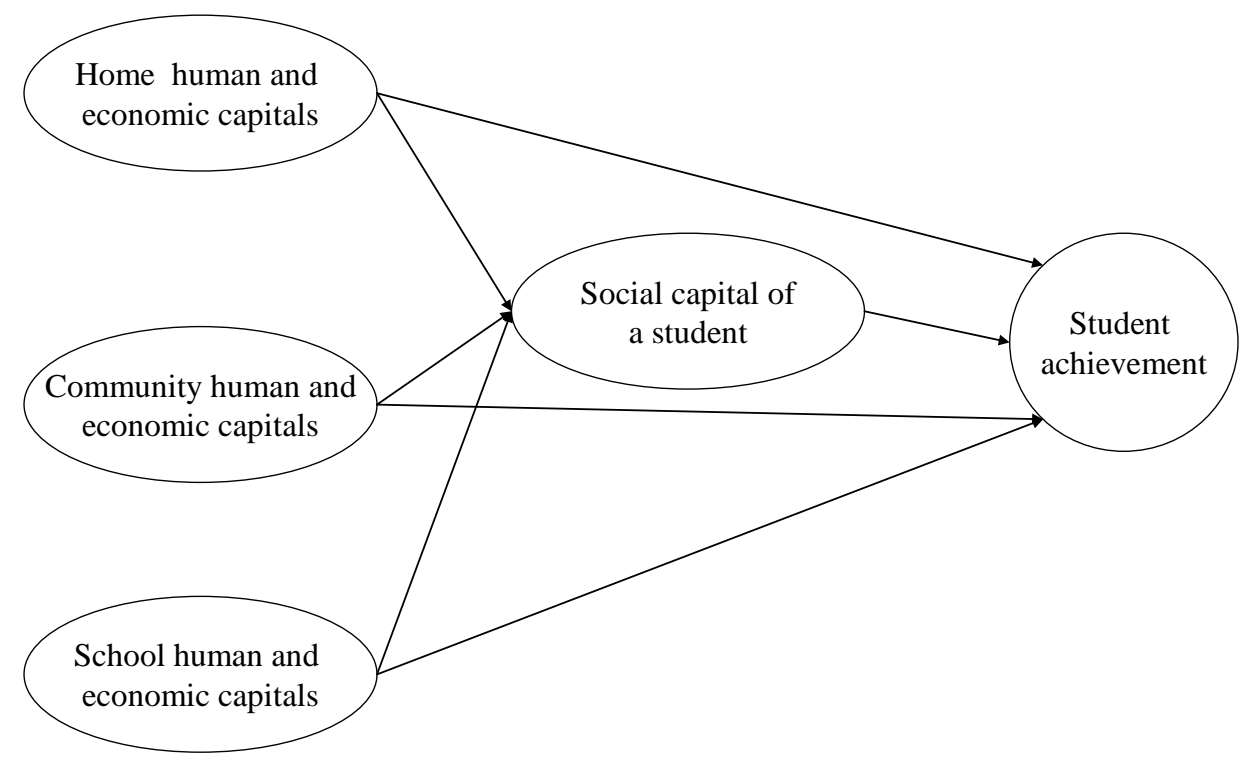

Figure 2. Analytical model linking students' backgrounds with social capital and academic achievement. Note: Reference: Huang (2009: pp. 320-325). Figure reproduced with the author’s permission. 
effects, via social capital, on student achievement. Moreover, resources derived from the social capital of a student directly influence school achievement while mediating the effects of the home, community and school environments.

Given the significance of school context, and the fact that a more level playing field potentially exists compared to home or community settings, the analysis which follows concentrates upon this milieu. The framework introduced above is tested with data taken from two national youth surveys in Norway and Romania respectively, which examine the relationship between student social capital and achievement in schools. This choice of countries, in addition to reflecting the areas of expertise of the authors, is grounded in the relative comparability of secondary education systems across these two contexts, as explained in the introductory discussion, and the existence of appropriate data. Added to these practical considerations is the desire to appreciate differences related to the contrasting character of these nations in relation to issues such as welfare regime, economic situation and cultural heritage. Can we say, for example, that secondary school pupils in a Nordic country such as Norway are characterized by a stronger or weaker relationship between social capital in educational institutions and academic achievement compared to the post-communist context of Romania? It is important to acknowledge that the rationale behind this comparison is not one of exploring national differences between two arbitrarily different societies, but rather one of illustrating the different effects of social capital in markedly different societies but in a generally similar educational context.

\section{Data and Methods}

The Norwegian data used in this study are from a national survey 2010 on school students, including 19 primary schools and 72 lower and upper secondary schools in Norway ("Young in Norway" 2010). This survey is the third wave of a large national youth cross-sectional survey with two previous data collections in the same schools in 1992 and 2002 respectively. Permission from the schools to participate was requested for each data collection. The survey included students from the last year of primary schools and excluded students from the last year of upper secondary schools. A total number of 11,659 students from grades 7 - 12 at aged 12 - 17 were invited to participate in the survey. The response rate was $72.8 \%$, and as according to ethical guidelines for social research in Norway (NESH 2006), children under the age of 15 were subject to the obtaining of parental consent for participating in any research and/or surveys. A total of 8,488 questionnaires were completed in one school hour during the months January to March in 2010. The data include information on student home background, student relationships with parents and friends, school satisfaction and adjustment, educational planning and occupational choice, problematic behaviour, body and self-image, organizational participation, sports and leisure activities, use of mobile telephone, use of computer and internet.

The data from Romania were collected during the months of October 2009 and January 2009 from 67 secondary schools in 11 counties and the capital city of Bucharest, using "The School Success Profile” (SSP) questionnaire (Bowen \& Richman 2001; Bowen, Rose, \& Bowen 2005). The SSP questionnaire contains 22 dimensions among which 15 dimensions characterize students’ social environment profile and seven dimensions present student individual adaptation profile. Out of 3000 randomly selected students of grades 6 - 13, 2695 of them between ages of 11 - 19 completed the questionnaire in one school hour. The response rate was 90\%. Our analyses use information SSP Romania data on students' home background, social environment (school, peers, neighbourhood and family), school attitudes and behaviour, and personal beliefs and well-being. Table 1 presents measures and descriptive statistics of variables in both datasets that are relevant for testing the analytical framework of social capital in a school context.

Although the numbers of cases differs between the two datasets, the means ages of the two student groups range from 14.72 in Romania to 14.93 in Norway are similar. There are also as many female pupils (as “ 1 ”) as males (as ' 0 ') in the Norwegian group while females are slightly over-represented in the Romania data. Immigrant or minority status is split into two main categories in both countries where " 0 ” represents the majority and ' 1 ' as minority. In Romania, the majority represents the Romanian while the minority (coded as 1 ) includes respondents of Roma and Hungarian ethnicity.1 In the Norwegian data, the majority represents students with at least one parent from one of the Nordic countries and minority with both parents from a non-Nordic country. Mother's and father's education is measured in both datasets as $1=$ lower secondary and lower level, $2=$ upper secondary level and 3 = tertiary level. As statistics show in Table 1, parents in Norway appear to be slightly more educated than the Romanian parents while Norwegian mothers are the parent group with highest education 
level followed by Norwegian fathers then Romania fathers and mothers. In the Norwegian data, academic achievement is measured by three most recent grades on subjects of Norwegian, Mathematics and English on a 1 - 6 scale while the academic achievement of the Romania students has only one measure on a 1 - 7 interval scale asking the average grades where " 1 " indicates an average grade falling between $4-4.99$ and "7" indicates an average grade between 9.51 to 10 (usually on a 1 to 10 scale of each subject) from the previous semester. For the purpose of comparison, we use an average score of the three subjects as the indicator for academic achievement of the Norwegian students.

In regard to the "social capital" dimension of the analysis, the analytic framework presented in Figure 2 included school context as a key component, along with community and home human and economic capitals. To locate indicators of levels of social capital among the respondents to both surveys, exploratory Factor Analysis was used to search for variables that were able to indicate distinct latent factors of interest. To allow a crosscountry comparison of the data, we included in the analysis only the social relation items that were measured in both datasets as they are shown as the 7 lines from the bottom of Table 1. The items correspond to three categories: student relationship with parents; student relationship with teachers; and student relationship with friends. However, measurements of the items are rather different: all items are on a 1 - 4, 1 - 5 or 1 - 6 point scale in the Norwegian data while mostly yes (" 1 ") or no ("0") choices are used for the items in the Romania data. Table 2 presents the factor loadings of three social capital constructs extracted from each of the two datasets. The

Table 1. Descriptive statistics of variables measuring student demographics, home background and social relations.

\begin{tabular}{ccccccccccccc}
\hline & \multicolumn{4}{c}{ Norwegian data } & \multicolumn{4}{c}{ Romanian data } \\
\cline { 2 - 11 } Age & $\mathrm{N}$ & Min. & Max. & Mean & Std. D & N & Min. & Max. & Mean & Std. D \\
\hline Sex (girl as 1) & 8455 & 12 & 21 & 14.93 & 1.84 & 2639 & 11 & 20 & 14.72 & 1.78 \\
Immigrant or minority as 1 & 8424 & 0 & 1 & 0.50 & 0.50 & 2681 & 0 & 1 & 0.54 & 0.50 \\
Mother's education attainment & 8230 & 0 & 1 & 0.07 & 0.25 & 2653 & 0 & 1 & 0.11 & 0.31 \\
Father's education attainment & 6598 & 1 & 3 & 2.36 & 0.61 & 2224 & 1 & 3 & 2.17 & 0.63 \\
Average grades & 6596 & 1 & 3 & 2.28 & 0.63 & 2186 & 1 & 3 & 2.19 & 0.60 \\
Parents always know my where about & 8853 & 0 & 6 & 3.83 & 0.85 & 2679 & 1 & 7 & 5.02 & 1.35 \\
My parents know my friends well & 8343 & 1 & 5 & 4.09 & 0.92 & 2337 & 0 & 1 & 0.90 & 0.31 \\
I had quarrel(s) with a teacher & 8243 & 1 & 6 & 1.32 & 0.75 & 2589 & 0 & 1 & 0.14 & 0.34 \\
I was sent to the principal for bad deeds & 8224 & 1 & 6 & 1.23 & 0.66 & 2599 & 0 & 1 & 0.05 & 0.22 \\
It is easy to make friends & 8350 & 1 & 4 & 3.35 & 0.77 & 2678 & 0 & 1 & 0.65 & 0.48 \\
I feel accepted by peers & 8351 & 1 & 5 & 4.67 & 0.74 & 2676 & 0 & 1 & 0.76 & 0.42 \\
I was never bullied by peers & 8187 & 1 & 4 & 3.33 & 0.67 & 2682 & 0 & 1 & 0.84 & 0.37 \\
\hline
\end{tabular}

Note: Valid N list wise: 5704 for Norway and 1636 for Romania.

Table 2. Component matrices of social capital in both datasets.

\begin{tabular}{ccccccc}
\hline & \multicolumn{3}{c}{ Norway } & \multicolumn{3}{c}{ Romania } \\
\cline { 2 - 7 } & 1 & 2 & 3 & 1 & 2 & 3 \\
\hline My parents always know my where about & $\mathbf{0 . 8 9 2}$ & -0.087 & 0.070 & $\mathbf{0 . 7 1 3}$ & -0.154 & 0.110 \\
My parents know my friends well & $\mathbf{0 . 8 9 6}$ & -0.088 & 0.036 & $\mathbf{0 . 8 2 0}$ & -0.009 & -0.044 \\
I had quarrel(s) with a teacher & -0.102 & $\mathbf{0 . 8 2 7}$ & -0.075 & -0.189 & $\mathbf{0 . 7 7 5}$ & 0.017 \\
I was sent to the principal for bad deeds & -0.066 & $\mathbf{0 . 8 3 2}$ & 0.003 & -0.003 & $\mathbf{0 . 8 1 0}$ & -0.093 \\
It is easy to make friends & 0.051 & 0.097 & $\mathbf{0 . 7 7 1}$ & 0.028 & 0.236 & $\mathbf{0 . 6 2 2}$ \\
I feel accepted by peers & -0.035 & -0.192 & $\mathbf{0 . 6 4 5}$ & 0.079 & -0.090 & $\mathbf{0 . 7 5 2}$ \\
I was never bullied by peers & 0.109 & -0.002 & $\mathbf{0 . 7 8 0}$ & -0.029 & -0.223 & $\mathbf{0 . 6 3 8}$ \\
\hline
\end{tabular}

Note: Extraction method: Principal Component Analysis. Rotation method: Varimax with Kaiser Normalisation. Total variance explained: 67.1\% for Norway and $57.2 \%$ for Romania. 
assignment of a meaningful name to each factor (i.e. factor 1 as “child-parent relation”, factor 2 as "studentteacher conflict”, and factor 3 as "peer relation”) allows the three factors to represent three forms of social capital a student possesses in three contexts (home, school and community). The component matrices show the same pattern of three social capital factors in both datasets except some minor differences in factor loadings. The total variances explained by the three extracted factors are different, which shows better measurement quality of the items in the Norwegian data (67.1\% variance explained) than those in the Romania data (57.2\% variance explained).

Once the variables for the latent construct of social capital are identified, confirmatory factor analysis is applied to determine whether the latent variables specified and the measurement model hypothesized actually fit the data. Figure 3 is the operational model corresponding to the analytical framework of this study shown in Figure 2. It presents hypothesized links between measures of seven latent variables to be tested by the data. Home human and economic capital is built around parental (both father's and mother's) educational attainment. The other two background variables are sex as proxy of gender and parental non-native or minority status as proxy of ethnicity. The model hypothesizes that background variables have both a direct and an indirect (via their influence on student social capital) effect on the dependent variable. The three latent social capital constructs are hypothesized in the model as mediating factors that are influenced by background variables while exerting effect on the dependent variable, i.e. academic achievement (average grades of the students).

Next, we test the two datasets on the hypothetical links between the variables (as shown in Figure 3), using linear structural equation techniques (LISREL). The LISREL technique is able to estimate not only the contributions of various factors in predicting the outcome variable but also unique information about the direct and indirect paths of reliable influence (Mueller, 1996; Ransdell, 2001; Ransdell et al., 2001). The reporting procedure of model test results follows criteria established in previous social science research. According to a classification of standardized regression weights (Desjardins, 2003) in social science research using population sample survey data, a regression weight over 0.30 is considered a very strong effect, from 0.20 to 0.30 is a strong effect, from 0.10 to 0.20 is a moderate effect and below 0.10 is a weak effect. The decision to accept or reject a hypothesized structural model is taken with reference to the fit statistics. Chi-square $\left(\chi^{2}\right)$ is most frequently cited as a measure of the overall goodness of fit of the model to the data (Jöreskog \& Sörbom, 1993). The Root Mean Square Residual (RMR) represents the average deviation of the predicted from the actual correlation matrix. The Good-offit Index (GFI) indicates the proportion of the joint amount of data variance and covariance that can be explained by the tested model. The common rule for an acceptable fit of a model is an RMR below 0.05 points, with AGFI (Adjusted Good-of-fit Index) and GFI exceeding 0.90 (Hoyle \& Panter, 1995; Tuijnman \& Keeves, 1997).

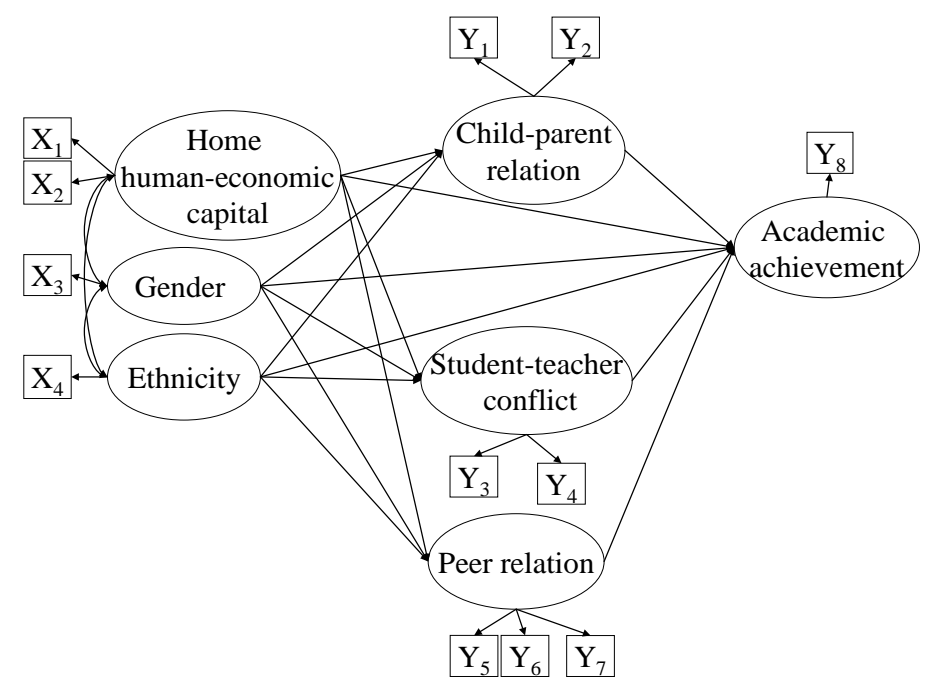

Figure 3. Path diagram for a hypothesized model of linking student background variables, social capital and academic achievement. (Note: Keys) $\mathrm{X}_{1}$ : Father's educational attainment; $\mathrm{X}_{2}$ : Mather’s educational attainment; $\mathrm{X}_{3}$ : Sex; $\mathrm{X}_{4}$ : Immigrant or minority status; $\mathrm{Y}_{1}$ : My parents always know my whereabouts; $\mathrm{Y}_{2}$ : My parents know my friends well; $\mathrm{Y}_{3}$ : I had quarrel(s) with a teacher; $\mathrm{Y}_{4}$ : I was sent to the principal for bad deeds; $\mathrm{Y}_{5}$ : It is easy to make friends; $\mathrm{Y}_{6}$ : I feel accepted by peers; $\mathrm{Y}_{7}$ : I was never bullied by peers; $\mathrm{Y}_{8}$ : Average grades. 


\section{Results}

Figure 4 is a visual presentation of test results of a linear structural model on the Norwegian and Romanian data linking student home human and economic capital, variables of student social capital and student achievement. Structural paths shown in Figure 4 have a similar pattern in both countries when it comes to the effect of background and social capital variables but the strength of path coefficients are rather different between the two student groups. First, home human and economic capital has a very strong positive effect on academic achievement in both countries, and it exerts a moderate positive effect on positive social relations such as a good child-parent relationship and a good peer relationships, while avoiding negative social relations such as student-teacher conflict in the case of Norway and a strong positive effect on good peer relations in the case of Romania. Second, being female is an advantage for positive social relations, such as a good child-parent relation and a good peer relation while it has a strong negative effect on student-teacher conflict in both countries. Third, having both parents as immigrants in Norway has a weak negative effect on both peer relation and academic achievement, while being a minority child in Romania has a weak negative effect to child-parent relation, contributes moderately to student-teacher conflict but has no significant effect on academic achievement directly. As of the social capital variables, while student-teacher conflict has a moderate negative effect on achievement in both countries, a good child-parent relation has a moderate positive effect on achievement in Norway and a strong positive effect in Romania. Peer relation has a weak positive effect on achievement for a Norwegian student but for a Romanian student this effect is not statistically significant.

Table 3 presents total, direct and indirect effects of factors on the academic achievement, providing additional information of the model test results visualized in Figure 3. Besides the direct effects of background variables
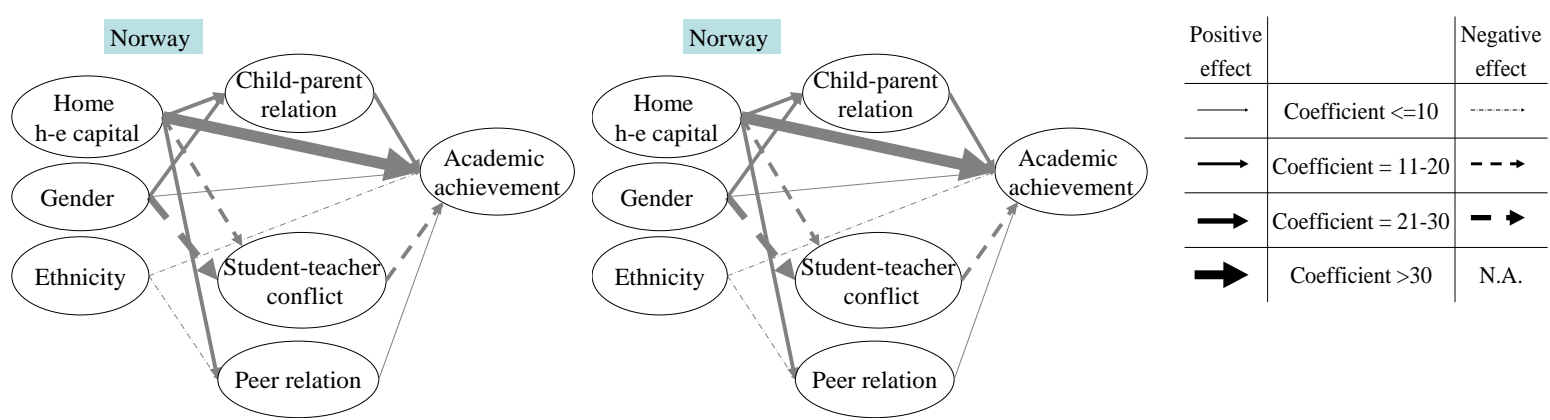

Figure 4. Strength of path coefficients in a model of testing the effect of social capital on academic achievement on Norwegian and Romanian data (direct effects only). Note: ML solution. Path coefficients not statistical significant at 0.05 level are closed down in the model and not presented in the figure. Fit statistics for the models: Norway: $\chi^{2} / \mathrm{df}: 12.22$; RMR: 0.04 ; GFI: 0.99; AGFI: 0.97. Romania: $\chi^{2} / \mathrm{df}$ : 3.55; RMR: 0.04; GFI: 0.98; AGFI: 0.97.

Table 3. Standardized maximum likelihood regression coefficients for total, direct and indirect effects of six predictors on academic achievement of school students in Norway and Romania.

\begin{tabular}{|c|c|c|c|c|c|c|}
\hline & \multicolumn{3}{|c|}{ Norway } & \multicolumn{3}{|c|}{ Romania } \\
\hline & Total effect & Direct effect & Indirect effect & Total effect & Direct effect & Indirect effect \\
\hline \multicolumn{7}{|l|}{ Independent variables } \\
\hline Home human-economic capital & 0.34 & 0.30 & 0.05 & 0.39 & 0.39 & - \\
\hline Gender & 0.11 & 0.05 & 0.06 & 0.26 & 0.14 & 0.12 \\
\hline Ethnicity & -0.03 & -0.03 & - & -0.04 & - & -0.04 \\
\hline \multicolumn{7}{|l|}{ Intermediating variables } \\
\hline Child-parent relation & & 0.13 & & & 0.22 & \\
\hline Student-teacher conflict & & -0.15 & & & -0.20 & \\
\hline Peer relation & & 0.06 & & & - & \\
\hline Variance explained & & $17 \%$ & & & $30 \%$ & \\
\hline
\end{tabular}

Note: - indicates an effect not significant at 0.05 level. Fit statistics for the models: Norway: $\chi^{2}$ /df: 12.22 ; RMR: 0.04; GFI: 0.99; AGFI: 0.97. Romania: $\chi^{2} / \mathrm{df}$ : 3.55; RMR: 0.04; GFI: 0.98; AGFI: 0.97 . 
on achievement, they background variables have indirect effects on achievement mediated by their effects on social capital variables. Home human and economic capital in Norway has an indirect positive on academic achievement in Norway via its bearing on all three social relationships of the child while home capital has only direct effects on achievement for its strong influence on peer relations has in turn produced no significant contribution to academic achievement of the Romanian students. Gender is a stronger factor in student achievement in Romanian but not Norwegian schools owing to a very strong influence on child-parent relation, and strong negative effect on student-teacher conflict. Ethnicity is a weak negative factor on achievement for both Norwegian and Romanian students but, working in a total different mechanism, it has only a direct effect in Norway and an indirect effect in Romania via its “contribution” to a bad social relationship, i.e. student-teacher conflict.

Moreover, the data from both countries appears to fit the model well judging by the fit statistics for the results presented in Figure 4 and Table 3. Background and social capital variables in the model happen to be stronger predictors for academic achievement of the Romanian students (30 percent variance explained) than their predicting power for that of the Norwegian students (17 percent variance explained).

\section{Discussion}

In interpreting these results, we can make three basic deductions about what we have learnt from the analysis. Firstly, home human and economic capital has a very strong positive and direct effect on student achievement in both cases, but its effect on social capital differs substantially between the two societies. While this home asset has an effect on every social relation of the Norwegian child, it exerts a strong effect only on the peer relation of the child in Romania which gives little in return to student achievement. What this seems to indicate is that parents in Norway are more influential in regard to their children's academic attainment, most likely to the fact that they possess higher levels of social capital as indicated by the proxy indicator of parental education attainment level (see Table 1). Secondly, gender turns out to be a much stronger factor influencing student achievement and social capital in Romania than in Norway. Excepting an equally strong negative effect on student-teacher conflict in both school systems, the Romanian female pupils have a very strong positive effect on a good child-parent relation compared to a moderate effect on that relationship of the Norwegian girls. In return, a good child-parent relation contributes to a much stronger positive effect on academic achievement of the Romanian girls than that of their Norwegian counterparts. Third, having an immigrant background in Norway or being a minority in Romania is a negative factor for achievement but its effect shows different social mechanisms. Immigrant background has a negative direct weak effect on achievement and peer relation of the Norwegian child, while being from a minority group in Romania contributes moderately to student-teacher conflict and poor child-parent relation, which in turn has a negative effect on achievement. In total, home human and economic capital is the strongest factor influencing achievement, while gender is the strongest factor influencing the social capital of students in both school systems. It appears that Romanian girls are much stronger in building good social relations while avoiding conflict in school than their Norwegian counterparts. Moreover, a good childparent relationship makes more contributions to the academic achievement of the Romanian child than to that of the Norwegian child. All these reflections help us move towards a better understanding of school success, providing evidence on the significance of social relationships, gender and having an immigrant background.

\section{Conclusion}

Putting these results into a broader theoretical context, these findings appear to support Coleman's social capital theory only in the Norwegian schools as home capital in Romania seems to invest in "wrong” social capital (i.e. peer relationships) which offers relatively little in return to contribute to achievement, thus highlighting the importance of national diversity in appreciating the importance of social capital in our educational context. An alternative explanation is suggested by a reading of Bourdieu's (1997), concerning cultural capital and social reproduction theory. In the Norwegian schools, home human and economic capital functions as we might expect it to function, i.e. helping the child build positive social capital and avoid negative relations such as conflict with teachers. However, home capital does not appear to work the same way in Romania, which presents us a picture of schooling as a field of cultural (and/or social) clash wherein the child is caught in between. Home capital is only an effective resource to locate the child on the academic achievement scale at school but it does little to help the child build social capital neither at school nor at home. It also appears to be the case that Romania parents make sure that their children end up in the "correct” peer group but this seems to have nothing to do with 
their academic achievement. Finally, being in a minority within a majority dominated society and school system, a minority child in Romania often finds her/himself in conflict with their significant adults (parents and teachers) which in turn, has a negative effect on his/her academic achievement.

On the whole, the statistical analyses show that background variables play a significant role in building student social capital, a result that positively influences achievement in both Norwegian and Romanian schools. An initial conclusion can hence be that social capital matters in respect to educational attainment in both these contexts. However, what is an interesting and, perhaps, surprising finding of this study is that there is a difference in how the background and social capital factors act and/or interact and on their influence on student achievement in the two "more similar than different" school systems. This means that our study has potential to add important nuances to our understanding of social capital in secondary level educational contexts through elaborating what these differences are.

While it is important to acknowledge the limits of our analysis, restricted as it is to Norway and Romania, some useful pointers are thus provided for future research. Not only the confirmation that social capital, and building social capital, matters in our educational contexts, but the fact that we can illustrate how to explore this process via our statistical model. Added to this reflection is the value gained from a comparative research design, helping to illustrate commonalities and divergences across different societies; for example, in the role played by parents in securing educational success. This is obviously a theme that can be extended to other national contexts, with different norms and values, and to different educational situations, providing a potential future application for our theoretical and methodological approach.

\section{Acknowledgements}

The data analysis of this work was supported by the European Science Foundation (ESF-QMSSII) under Short Visit Grant (nr.3802 \& nr.2807).

\section{Notes}

The Hungarian minority is more similar to the Romanian population in terms of home human capital than to the Roma minority; however, the two categories were mixed because of the low number of Roma respondents.

\section{References}

Agabrian, M. (2007). Relationships between School and Family: The Adolescents' Perspective. Forum: Qualitative Social Research, 8, Art. 20. http://nbn-resolving.de/urn:nbn:de:0114-fqs0701208 .

Astone, N. M., Constance, A. N., Schoen, R., and Kim, Y. J. (1999). Family Demography, Social Theory, and Investment in Social Capital. Population and Development Review, 25, 1-31. http://dx.doi.org/10.1111/j.1728-4457.1999.00001.x

Bourdieu, P. (1997). The Forms of Capital. In A.H. Halsey (Ed.), Education: Culture, Economy and Society (pp. 241-258). Oxford: Oxford University Press.

Bowen, G. L., \& Richman, J. M. (2001). School Success Profile. Chapel Hill, NC: The University of North Carolina, School of Social Work, Jordan Institute for Families.

Bowen, G. L., Rose, R. A., \& Bowen, N. K. (2005). The Reliability and Validity of the School Success Profile. Philadelphia, PA: Xlibris Press.

Buru-Bellat, M. (2004). Social Inequality at School and Educational Policy. Fundamentals of Educational Planning. Paris: IIEP, UNESCO.

Cabrera, A. F., \& La Nasa, S. M. (2001). On the Path to College: Three Critical Tasks Facing America's Disadvantaged. Research in Higher Education, 42, 119-149. http://dx.doi.org/10.1023/A:1026520002362

Cairns, D. (2014). Youth Transitions, International Student Mobility and Spatial Reflexivity: Being Mobile? Basingstoke: Palgrave Macmillan. http://dx.doi.org/10.1057/9781137388513

Cairns, D., Growiec, K., \& Smyth, J. (2013). Leaving Northern Ireland: The Youth Mobility Field, Habitus and Recession among Undergraduates in Belfast. British Journal of Sociology of Education, 34, 544-562. http://dx.doi.org/10.1080/01425692.2012.723869

Choy, S. P., Horn, L. J., Nuñez, A., \& Chen, X. (2000). Transition to College: What Helps At-Risk Students and Students Whose Parents Did Not Attend College? In A. F. Cabrera \& S. M. La Nasa (Eds.), Understanding the College Choice of Disadvantaged Students (pp. 241-258). San Francisco, CA: Jossey-Bass.

Coleman, J. S. (1988). Social Capital in the Creation of Human Capital. American Journal of Sociology, 94, 94-120. 
http://dx.doi.org/10.1086/228943

Dămean, D., Roth, M., \& Hărăguș, T. P. (2010). Social Dimensions of School Success in Romania: A Comparison with USA Data. The International Journal of Learning, 17, 367-380.

Desjardins, R. (2003). Determinants of Economic and Social Outcomes from a Life-Wide Learning Perspective in Canada. Education Economics, 11, 11-38. http://dx.doi.org/10.1080/09645290210127462

Erikson, R., \& Jonsson, J. O. (1998). Social Origin as an Interest-Bearing Asset: Family Background and Labour-Market Rewards among Employees in Sweden. Stockholm: Swedish Institute for Social Research, Stockholm University.

Field, J. (2003). Social Capital. London: Routledge.

Güzel, C. I., \& Berberoglu, G. (2005). An Analysis of the Programme for International Student Assessment 2000 (PISA 2000) Mathematical Literacy Data for Brazilian, Japanese and Norwegian Students. Studies in Educational Evaluation, 31, 283-314. http://dx.doi.org/10.1016/j.stueduc.2005.11.006

Harding, D. J. (2003). Counterfactual Models of Neighborhood Effects: The Effects of Neighborhood Poverty on Dropping out and Teenage Pregnancy. American Journal of Sociology, 109, 368-385. http://dx.doi.org/10.1086/379217

Hatos, A. (2008). The Impact of Segregation and Differentiation on School Performance in Grades 10-12: A Multi-Level Analysis (Impactul segregării şi diferenţierii asupra performanţelor şcolare ale elevilor din clasele 10-12: O analiză multinivel). Quality of Life / Calitatea Vieți, 19, 141-158.

Hill, P. W., \& Rowe, K. J. (1996). Multilevel Modeling in School Effectiveness Research. School Effectiveness and School Improvement, 7, 1-34. http://dx.doi.org/10.1080/0924345960070101

Hill, P. W., \& Rowe, K. J. (1998). Modeling Educational Effectiveness in Classrooms: The Use of Multilevel Structural Equations to Model Students’ Progress. Educational Research and Evaluation, 4, 307-347. http://dx.doi.org/10.1076/edre.4.4.307.6953

Hoyle, R. H., \& Pantere, A. T. (1995). Writing about Structural Equations Models. In R. H. Hoyle (Ed.), Structural Equation Modelling: Concepts, Issues, and Applications. London: Sage Publications.

Hu, S. P. (2003). Educational Aspirations and Postsecondary Access and Choices: Students in Urban, Suburban, and Rural Schools Compared. Educational Policy Analysis Archives, 11, 1-13. http://epaa.asu.edu/ojs/article/view/242

Huang, H., \& Sebastian, J. (2014). The Role of Schools in Bridging Within-School Achievement Gaps Based on Socioeconomic Status: A Cross-National Comparative Study. Compare: A Journal of Comparative and International Education, 45 , 501-525. http://dx.doi.org/10.1080/03057925.2014.905103

Huang, L. (2008). How Different Are They? Students Receiving Learning Assistance in the Classroom in Norwegian Secondary Schools. In D. M. McInercey, \& A. D. Liem (Eds.), Teaching and Learning: International Best Practice. Greenwich, CT: Information Age Press.

Huang, L. (2009a). Gender Segregation in Student Career Aspirations in Norwegian Secondary Schools. In D. P. Baker, \& A. W. Wiseman (Eds.), Gender, Equality and Education from International and Comparative Perspectives. International Perspectives on Education and Society (Vol. 10, pp. 333-357). Bingley: Emerald Group Publishing Limited. http://dx.doi.org/10.1108/S1479-3679(2009)0000010013

Huang, L. (2009b). Social Capital and Student Achievement in Norwegian Secondary Schools. Learning and Individual Differences, 19, 320-325. http://dx.doi.org/10.1016/j.lindif.2008.11.004

Huang, L. (2010). Peer Relations and Student Achievement in the Norwegian Secondary Schools. The International Journal of Learning, 16, 295-306.

Husén, T. (1989). Higher Education and Social Stratification: An International Comparative Study. Paris: IIEP, UNESCO.

Jigău, M. (Ed.) (2002). Rural Education in Romania: Conditions, Problems and Strategies for Development (Învăţământul rural din România. Condiţii, probleme şi strategii de dezvoltare). Bucureşti: MarLink.

Jöreskog, K. G., \& Sörbom, D. (1993). LISREL 8: Users’ Reference Guide. Chicago, IL: Scientific Software.

Krange, O., \& Bakken, A. (1998). School Achievement of the Immigrant Youth: Traditional Class Difference or New Dividing Line? (Innvandrerungdoms skoleprestasjoner. Tradisjonelle klasseskiller eller nye skillelinjer?) Tidsskrift for samfunnsforskning, 39, 381-410.

Lauglo, J. (1996). Uphill, but with More Drive? Immigrant Youth in Norwegian Schools (Motbakke, men mer driv? Innvandrerungdom i norsk skole). Rapport 6/98, Oslo: NOVA.

Lauglo, J. (2008). Family Structures and School Achievements (Familiestruktur og skoleprestasjoner). Tidsskrift for ungdomsforskning, 8, 3-29.

Lie, S., Kjærnsli, M., Roe, A., \& Turmo, A. (2001). Good Results for the Future? Norwegian 15 Years Olds' Competence in Reading and Science in an International Perspective (Godt rustet for framtida? Norske 15-åringers kompetanse i lesing og realfag i et internasjonalt perspektiv). Rapport 4/2001, Oslo: Institutt for lærerutdanning og skoleutvikling, University of Oslo. 
Lin, N. (2001). Social Capital: A Theory of Social Structure and Action. Cambridge: Cambridge University Press. http://dx.doi.org/10.1017/CBO9780511815447

Markussen, E., Strømstad, M., Carlsten, T. C., Hausstätter, R., \& Nordahl, T. (2007). Inclusive Special Education? On Challenges within the Special Education in 2007 (Inkluderende spesialundervisning? Om utfordringer innefor spesialundervisningen i 2007). Rapport, 19, Oslo: NIFU-STEP.

McDaniel, A. (2010). Cross-National Gender Gaps in Educational Expectations: The Influence of National-Level Gender Ideology and Educational Systems. Comparative Education Review, 54, 27-50. http://dx.doi.org/10.1086/648060

McDonough, P. M. (1997). Choosing Colleges: How Social Class and Schools Structure Opportunity. Albany, NY: State University of New York Press.

Meier, A. (1999). Social Capital and Academic Achievement among Adolescents. Working Paper 99-18, Madison, WI: University of Wisconsin-Madison, Centre for Demography and Ecology.

Miclea, M. (2005). Report on the Current Situation of the Education System (Raport asupra stării sistemului de învăţământ). Bucureşti. http://www.edu.ro/index.php/genericdocs/3590

Mueller, R. O. (1996). Basic Principles of Structural Equation Modelling: An Introduction to LISREL and EQS. New York: Springer. http://dx.doi.org/10.1007/978-1-4612-3974-1

OECD, Organization for Economic Cooperation and Development (2005). Education at a Glance 2005. Paris: OECD.

Olsen, R. V. (2003). Student and Teacher Behavior. In S. Lie, P. Linnakylä, \& A. Roe (Eds.), Northern Lights on PISA: Unity and Diversity in the Nordic Countries in PISA 2000 (pp. 113-122). Oslo: University of Oslo.

Portes, A. (1998). Social Capital: Its Origins and Applications in Modern Sociology. Annual Review of Sociology, $24,1-24$. http://dx.doi.org/10.1146/annurev.soc.24.1.1

Putnam, R. D. (1993). Making Democracy Work: Civic Traditions in Modern Italy. Princeton, NJ: Princeton University Press.

Putnam, R. D. (2000). Bowling Alone: The Collapse and Revival of American Community. New York: Simon and Schuster. http://dx.doi.org/10.1145/358916.361990

Ransdell, S. (2001). Chapter 4: Discussion and Implications. International Journal of Educational Research, 35, $391-395$. http://dx.doi.org/10.1016/S0883-0355(01)00035-0

Ransdell, S., Hawkins, C., \& Adams, R. (2001). Chapter 2: Models, Modelling, and the Design of the Study. International Journal of Educational Research, 35, 365-372. http://dx.doi.org/10.1016/S0883-0355(01)00033-7

Rowe, K. J. (1997). Factors Affecting Students' Progress in Reading: Key Findings from a Longitudinal Study. In S. L. Swartz, \& A. F. Klein (Eds.), Research in Reading Recovery (pp. 57-110). Portsmouth, NH: Heinemann.

Sandefur, G. D., \& Wells, T. (1999). Does Family Structure Really Affect Educational Attainment. Social Science Research, 28, 331-357. http://dx.doi.org/10.1006/ssre.1999.0648

Sandefur, G. D., Meier, A., \& Campbell, M. (2006) Family Resources, Social Capital and College Attendance. Social Science Research, 35, 525-553. http://dx.doi.org/10.1016/j.ssresearch.2004.11.003

Sandefur, R. L., \& Laumann, E. O. (1998). A Paradigm for Social Capital. Rationality and Society, 10, 481-501. http://dx.doi.org/10.1177/104346398010004005

Schoen, R., Kim, Y. J., Nathoanson, C. A., Fields, J., \& Astone, N. M. (1997). Why Do Americans Want Children? Population and Development Review, 23, 333-358. http://dx.doi.org/10.2307/2137548

Silova, I., \& Magno, C. (2004). Gender Equity Unmasked: Democracy, Gender, and Education in Central/South-Eastern Europe and the Former Soviet Union. Comparative Education Review, 48, 417-442. http://dx.doi.org/10.1086/423358

Stanton-Salazar, R. D., \& Dornbusch, S. M. (1995). Social Capital and the Reproduction of Inequality: Information Networks among Mexican-Origin High School Students. Sociology of Education, 68, 116-135. http://dx.doi.org/10.2307/2112778

Teachman, J., Paasch, K., \& Carver, K. (1996). Social Capital and Dropping out of School Early. Journal of Marriage and the Family, 58, 773-783. http://dx.doi.org/10.2307/353735

Tufiş, P. A. (2008). Predictors of School Success in Romania: Family Background, School Factors, and Community Factors. Quality of Life / Calitatea Vieţii, 19, 389-405.

Tuijnman, A. C., \& Keeves, J. P. (1997). Path Analysis and Linear Structural Relations Analysis. In J. P. Keeves (Ed.), Educational Research Methodology and Measurement: An International Handbook (2nd ed., pp. 621-633). Oxford: Pergamon Press and Elsevier Science.

UNESCO, United Nations Educational, Scientific and Cultural Organization (2012). World Atlas of Gender Equality in Education. Paris: UNESCO.

World Bank (2012). World Development Report 2012: Gender Equality and Development. Washington DC: The World Bank. 